\title{
THE LENDING OF AGRICULTURAL PRODUCERS IN UKRAINE
}

\author{
Tetiana Mulyk', Yaroslavna Mulyk²
}

\begin{abstract}
The purpose of the paper is to analyze and study the issues of lending to agricultural producers in Ukraine. Methodology. General scientific economic and mathematical methods as analysis, synthesis, abstraction, concretization, and special methods as comparison, tabular were used. Results of the study have shown that banks are actively involved in lending to agricultural producers, including microcredit. The volumes of short-term loans of banks of agricultural enterprises, including small and micro enterprises during 2013-2018 were studied. The rating of domestic banks that offer the most favorable lending conditions for agricultural enterprises is also studied. It is determined that the microcredit mechanism, presented in Ukraine as the support for small business, was first mentioned in the Procedure for using funds provided in the State Budget for 2004 for financial support of farms through the microcredit mechanism of March 17, 2004, No. 325. Currently, such support regarding the partial compensation of interest on loans from commercial banks and the reduction in the cost of loans also exists. The procedure for lending to agricultural enterprises in 2018 and 2019 is analyzed. In particular, the number of agricultural enterprises, which attracted soft loans in 2015-2018 and the volume of soft loans, attracted by agricultural enterprises in this period, were estimated. Practical implications. Factors, that hinder the development of microcredit in Ukraine, have been identified. The basic directions of the further development of microcredit of subjects of small agrarian business are defined. It is determined, that the microcredit market provides conditions for stable development of the domestic economy, and the result of the use of microcredit should be the development of production aimed at priority sectors of the economy, including agriculture, the production of competitive products, and providing high-quality services.
\end{abstract}

Key words: crediting, microcredit, agrarian sector, support of the small business.

JEL Classification: Q10, Q12, Q14

\section{Introduction}

Agriculture is one of the priorities, strategically important sectors of the national economy. The agricultural sector is a leader for the Ukrainian economy, which plays an important role in the formation of gross product, export potential, food security of the country, employment, etc. Over the last decade, including the years of crisis, the industry has shown a positive financial result, which contributes to the competitiveness of domestic products in foreign markets, fertile land in favorable climatic conditions, a highly skilled workforce, developed transport infrastructure, etc. However, a study of the financial security of agricultural producers shows that they work mainly from their resources, which are now significant in proportion, but insufficient for self-financing. Limited own funds make agricultural enterprises hope

\footnotetext{
Corresponding author:

${ }^{1}$ Vinnytsia National Agrarian University, Ukraine.

E-mail: mulyk t o@ukr.net

ORCID: https://orcid.org/0000-0003-1109-2265

ResearcherID: L-5677-2018

${ }^{2}$ Vinnytsia National Agrarian University, Ukraine.

E-mail: mulyk.yaroslavna@ukr.net

ORCID: https://orcid.org/0000-0002-8166-2481

ResearcherID: L-5837-2018
}

for support from the state and determine the need to develop the relations to attract funds.

For agricultural production, the problem of access to credit resources is always relevant. Current banking products have a fairly high usage fee, they are not available to most manufacturers. At the same time, agricultural holdings can use international loans, where the rate is more acceptable. To level the playing field, the state should take care of agricultural producers who need to support their financial resources.

Under such conditions, the issue of financing small business, which is quite well developed in the agricultural sector, is important, where one of the important sources is lending, where an important role is played by microcredit carried out by domestic banks, non-banking institutions, foreign banking institutions and various funds. 


\section{Literature review}

A significant contribution to the assessment of the lending market is being studied by many scientists: M.Ya. Demyanenko, O.D. Vasylyk, I.M. Bryukhovetsky, B.K. Zbarsky, R.A. Layko, I.O. Lyuty, V.P. Ryabokon, G.M. Podlisetsky, A.M. Podderogin, D.V. Polozenko, V.M. Fedosov, S.I. Yuriy, V.G. Andriychuk, I.G. Kyrylenko, O. Babiak, M.M. Baranovskyi, R. Kotsovska, A. Kudinov, O. Kuzhel, O. Masna, and other scientists. However, the problem of financial support for microcredit for small and medium-sized businesses in the domestic literature and publications of scientists is insufficiently developed and covered. Lack of scientific works that would comprehensively consider and thoroughly reflect: the economic nature, role and place of microcredit; features of its implementation in the agricultural sector; the state and sources of financial resources for lending to small businesses in the agricultural sector; problems and directions of improving lending.

\section{The role of microcredit of that origin}

Microcredit is a relatively new and, as international experience shows, the most effective form of credit cooperation between banking institutions and small and medium-sized businesses. Today, the use of microcredit mechanisms is one of the main trends in the development of relations between small and medium-sized businesses and the banking sector. At the same time, the further effective development of microcredit requires a broad scientific substantiation of existing domestic and foreign experience in this field and the development of new theoretical concepts of implementation of microcredit activities.

Microcredit was first used in 1983 in Bangladesh, one of the world's poorest countries. And the man who invented small loans for the poorest of his fellow citizens, Muhammad Yunus, won the Nobel Peace Prize in 2006. At that time, microcredit took root not only in the poorest and developing countries but also in the countries with the stable and developed economy (Kiyoshi, 2005).

In general, the main idea of microfinance correlates with the idea of social entrepreneurship and is to overcome poverty, ensure the economic sustainability of socially vulnerable groups of the population and support their integration into the labor market through the development of small businesses.

The current interest in microcredit stems from the Microcredit Summit on February 2-4, 1997 in Washington. The definition of microcredit developed at the summit was: microcredit is a program designed to extend small loans to very poor people, their incomegenerating self-employment projects, thus enabling them to take care of themselves and their families (Kiyoshi, 2005).
As you can see, the main requirements for microcredit are a small loan amount and its issuance for a short period.

\section{The state of lending in the agricultural sector}

The functioning of microcredit in the agricultural sector of the economy is directly related to the problems of microfinance of households in rural areas. It does not make sense to consider microcredit in the agricultural sector of the economy in isolation from microfinance in rural areas. The latter are not only producers of agricultural products, but also the basis of rural communities. Today, small business plays an important role in the development of Ukraine's agricultural sector, agricultural production and job creation in rural areas. This is confirmed by the data presented in Figure 1, on the number of small enterprises operating in agriculture in Ukraine. As we can see, the share of small enterprises (farmers, peasant farms) is significant, it is $97 \%$ and according to statistics, it is growing in dynamics.

The issues of financing small farms are relevant in terms of stabilization and development of Ukraine's economy. The share of small forms of management reaches $1 / 2$ in the structure of gross agricultural output, with farmers accounting for no more than $8 \%$, the rest for farmers.

In Ukraine, microcredit is developing. Among the forms of loans to farmers and support for microcredit, there can be distinguished: direct government lending, non-government lending, government loan guarantee, non-government loan guarantee.

Regarding bank lending, it should be noted that banks are actively involved in lending to agricultural producers, including microcredit.

Forms of financial and credit support for microcredit for small businesses and practical methods of their application are the following:

Forms of financial and credit support for small business microcredit:

- Direct government lending;

- Non-government lending;

- State loan guarantee;

- Non-state loan guarantee.

Practical methods of application:

- direct guaranteed government loans; preferential government lending; creation of preferential conditions for obtaining loans; formation of state credit lines;

- banking system: lending by commercial banks; international financial assistance;

- non-banking system: lending by financial non-banking institutions (business support funds, mutual financing companies);

- guaranteeing and insuring MP loans at the expense of the state fund of funds or with the participation of the state in non-state guarantee funds; provision of state guarantees to non-state guarantee funds; 


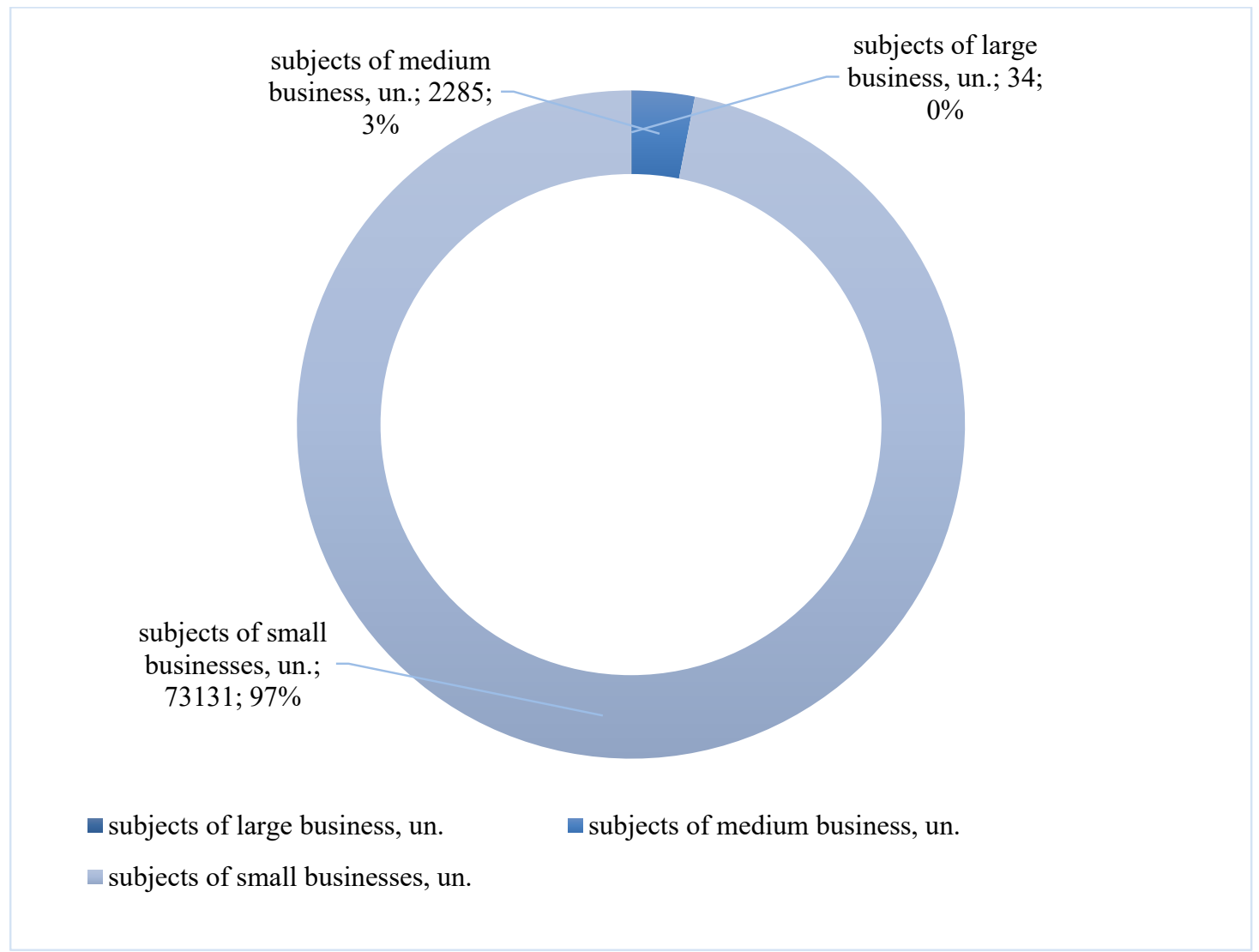

Figure 1. Number of business entities (enterprises) in agriculture in 2019 (Activities of large, medium, small and micro enterprises: a statistical collection, 2020)

- guaranteeing and insuring MP loans at the expense of independent non-governmental financial institutions or their associations through the creation of guarantee funds (Mulyk T. and Mulyk Y., 2020).

As you can see, the volume of short-term loans in the agricultural sector is accounted for by small and micro enterprises, but we must remember that there are more of them.

Volumes of short-term loans of banks of agricultural enterprises, including small and micro enterprises are given in Table 1.

Thus, in 2019 the volume of loans to small enterprises amounted to $23,293.3$ million UAH that is increased, compared to 2013 by $17,978.1$ million UAH. The share of loans to these entities increased by $20.63 \%$. Among loans to small enterprises in the agricultural sector, a significant share falls on loans to microenterprises, their share ranges from 30-58\%. During the study period, there was a slight decrease in the share of loans to micro-enterprises $(-6.32 \%)$.

Landlord magazine together with the audit and consulting company Kreston GCG found out who and on what terms are ready to finance Ukrainian farmers. The rating of Ukrainian banks (Table 2), which offer the most attractive conditions for lending and support to farmers, was created by Kreston GCG on the basis of a survey of financial institutions.
The questionnaire included general questions about the bank's policy on lending to farmers, specific proposals in the field of credit programs and partnership proposals, current credit products, restrictions on the profiles of companies that can be credited, etc. (Reliable leverage: TOP-15 banks lending to the agricultural sector, 2018).

The microcredit mechanism presented by the state as support for small business was first mentioned in the Order for using funds provided in the State Budget for 2004, for financial support of farms through the microcredit mechanism from 17.03.2004, No. 325 (Radchenko and Lazutina, 2018).

At present, this problem is partially solved by compensation from the budget for interest rates on loans, for certain programs, the study of which we have carried out before. In particular, the program "Financial support for measures in the agro-industrial complex by reducing the cost of loans", the funds of which are directed to economic entities of the agro-industrial complex for partial compensation of interest rates on bank loans, attracted in the national currency, has been operating since 2015. It is based on the Law of Ukraine "On State Support of Agriculture of Ukraine" of 24.06.2004 No. 1877 and the Resolution of the Cabinet of Ministers "On approval of the Procedure for using funds provided in the state budget for financial support 
Table 1

Volumes of short-term bank loans to agricultural enterprises

\begin{tabular}{|c|c|c|c|c|c|c|c|c|}
\hline \multirow{2}{*}{ Years } & \multicolumn{4}{|c|}{ Types of enterprises } \\
\cline { 2 - 9 } & \multicolumn{2}{|c|}{ large enterprises } & \multicolumn{2}{|c|}{ medium enterprises } & \multicolumn{3}{c|}{$\begin{array}{c}\text { small enterprises } \\
\text { enterprises }\end{array}$} \\
\cline { 2 - 9 } & million UAH & $\%$ & million UAH & $\%$ & million UAH & \% & million UAH & \% \\
\hline 2013 & 3050.3 & 13.66 & 13962.7 & 62.53 & 5315.2 & 23.80 & 2316.7 & 43.59 \\
\hline 2014 & 4141.3 & 14.99 & 15588.7 & 56.42 & 7899.9 & 28.59 & 4600.5 & 58.23 \\
\hline 2015 & 3694.8 & 13.27 & 14113.4 & 50.68 & 10040.9 & 36.05 & 4687.9 & 46.69 \\
\hline 2016 & 2562.1 & 8.82 & 16238.1 & 55.88 & 10257.8 & 35.30 & 5983.7 & 58.33 \\
\hline 2017 & 2179.5 & 4.65 & 25599.4 & 54.64 & 19074.6 & 40.71 & 6224.8 & 32.63 \\
\hline 2018 & 1603.8 & 2.92 & 27896 & 50.86 & 25347.6 & 46.21 & 8448.1 & 33.33 \\
\hline 2019 & 4356.1 & 8.31 & 24777.3 & 47.26 & 23293.3 & 44.43 & 8680.1 & 37.26 \\
\hline $2019 / 2013(+,-)$ & 1305.8 & -5.35 & 10814.60 & -15.3 & 17978.10 & 20.63 & 6363.40 & -6.32 \\
\hline
\end{tabular}

Source: formed by the author on the basis of (Activities of large, medium, small and micro enterprises: a statistical collection, 2020)

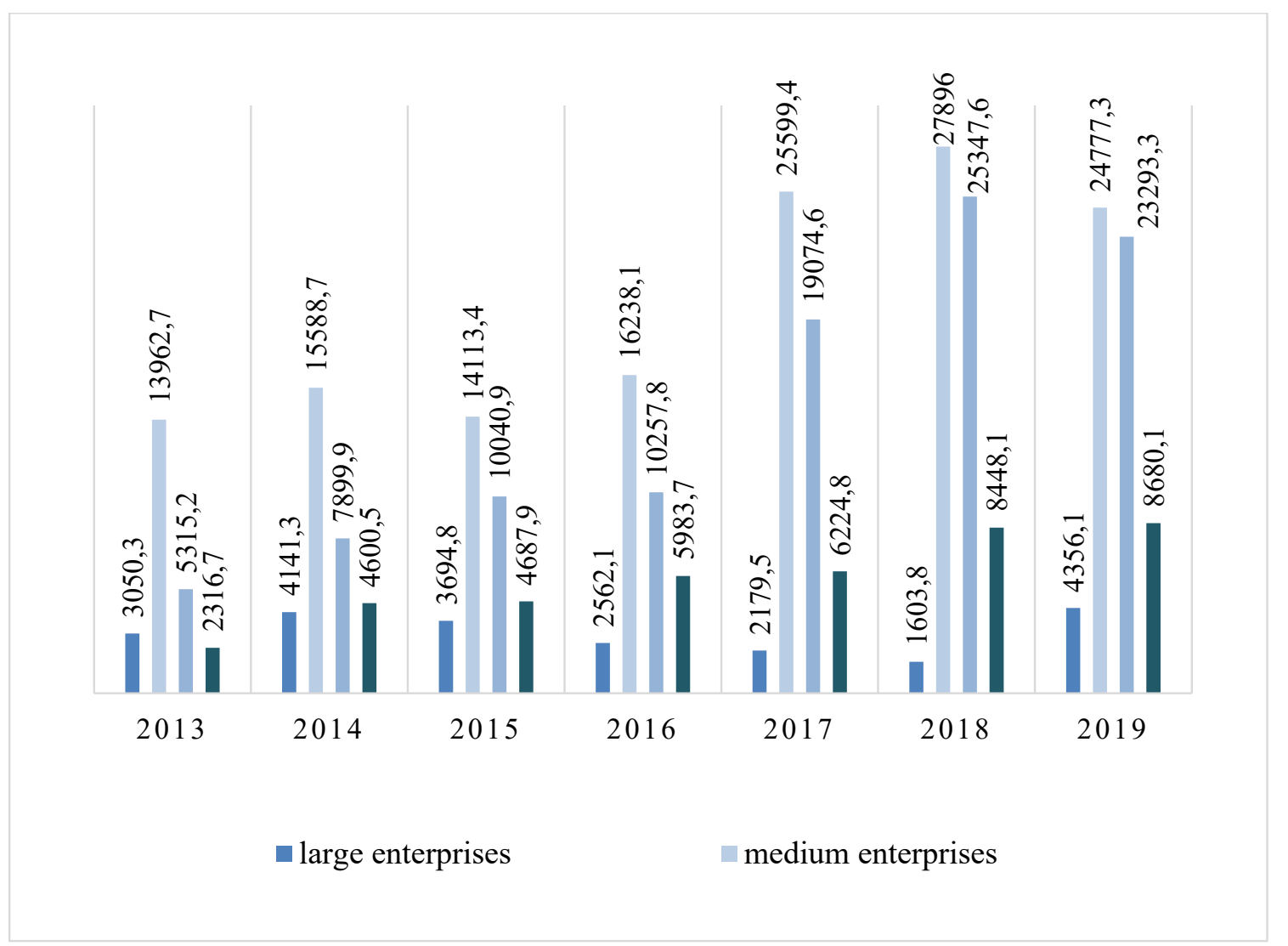

Figure 2. Volumes of short-term loans of banks of agricultural enterprises, million UAH (Activities of large, medium, small and micro enterprises: a statistical collection, 2020)

of measures in the agro-industrial complex by reducing 233 loans" No. 300 of 29.04.2015.

The Law of Ukraine "On the State Budget of Ukraine for 2020" ("On the State Budget of Ukraine for 2020: Law of Ukraine”, 2019) provides for expenditures under the program 1201300 "Formation of the authorized capital of the Partial Loan Guarantee Fund" in the amount of 240 million UAH. The program's passport does not exist yet, it is likely to be the successor of the still existing compensatory credit operations. 4 billion UAH has also been pledged on the program
1201150 "Financial support of agricultural producers", which is not listed in the directions, but is presented as the support for the purchase of land.

\section{Problems and directions of small business lending development in the agricultural sector}

In general, assessing the characteristics of the microcredit market in Ukraine and its positive developments, Z. Sorokivska notes the low level of its development. Factors that, in her opinion, hinder the 
Table 2

Ukrainian banks that offer the most attractive conditions for lending and support to farmers

\begin{tabular}{|c|c|c|c|c|}
\hline Bank & Credit limit & Rate & $\begin{array}{c}\text { Banking } \\
\text { commission }\end{array}$ & Lending programs \\
\hline OTP Bank & $\begin{array}{l}\text { from } 25,000 \mathrm{UAH} \\
\text { to more than } \\
10,000,000 \mathrm{UAH}\end{array}$ & $\begin{array}{l}\text { in hryvnia }-9.5-17 \%, \\
\text { in dollars }-5.5 \% \\
\text { in euros }-5 \%\end{array}$ & $\begin{array}{l}\text { depends on the } \\
\text { terms of the specific } \\
\text { agreement }\end{array}$ & $\begin{array}{l}\text { capital financing, investment loans, } \\
\text { credit line, overdraft, deposit loans, factoring, } \\
\text { bank guarantees, agricultural receipts. }\end{array}$ \\
\hline $\begin{array}{c}\text { Raiffeisen Bank } \\
\text { Aval }\end{array}$ & $\begin{array}{l}\text { from } 50,000 \mathrm{UAH} \text { to } \\
\text { more than } 10,000,000 \\
\text { UAH }\end{array}$ & $\begin{array}{l}\text { in hryvnia }-16 \% \text {, } \\
\text { in dollars }-6.5 \% \text {, } \\
\text { in euro }-5 \%\end{array}$ & $\begin{array}{l}0.5 \% \text { of the loan } \\
\text { amount }\end{array}$ & $\begin{array}{c}\text { capital financing, investment loans, credit line, } \\
\text { overdraft, deposit loans, factoring, promissory } \\
\text { note programs, bank guarantees, agricultural } \\
\text { insurance }\end{array}$ \\
\hline $\begin{array}{l}\text { First Ukrainian } \\
\text { International } \\
\text { Bank (FUIB) }\end{array}$ & $\begin{array}{l}\text { in the absence of } \\
\text { collateral - up to } \\
35 \text { million UAH, } \\
\text { in the presence - } \\
250 \text { million UAH }\end{array}$ & $\begin{array}{l}\text { in hryvnia }-19 \% \text {, } \\
\text { in dollars }-8.5 \% \text {, } \\
\text { in euro }-7.5 \%\end{array}$ & $\begin{array}{l}0.5 \% \text { of the loan } \\
\text { amount }\end{array}$ & $\begin{array}{l}\text { capital financing, investment loans, } \\
\text { credit lines, deposit loans, factoring, } \\
\text { promissory note avalization, bank guarantees, } \\
\text { agricultural receipts }\end{array}$ \\
\hline Mega Bank & up to 30 million $\mathrm{UAH}$ & $\begin{array}{c}\text { hryvnia }-20 \% \text {, } \\
\text { in foreign currency - } \\
8-9 \%\end{array}$ & $\begin{array}{l}1 \% \text { of the loan } \\
\text { amount }\end{array}$ & $\begin{array}{l}\text { microloans, promissory notes, } \\
\text { bank guarantees and others }\end{array}$ \\
\hline Oschadbank & $\begin{array}{l}\text { with collateral } \\
\text { is absent, without } \\
\text { collateral - } \\
10 \text { million UAH }\end{array}$ & $\begin{array}{l}\text { in hryvnia - from } \\
16.9 \% \text {, in foreign } \\
\text { currency }-7.5-8.5 \%\end{array}$ & $\begin{array}{l}0.2 \% \text { of the loan } \\
\text { amount }\end{array}$ & $\begin{array}{l}\text { working capital financing, investment loans, } \\
\text { financial leasing, promissory notes, etc. }\end{array}$ \\
\hline ProCredit Bank & $\begin{array}{l}\text { from } 2,000,000 \mathrm{UAH} \\
\text { to } 10,000,000 \mathrm{EUR}\end{array}$ & $\begin{array}{l}\text { in hryvnia - } 16-18 \% \text {, } \\
\text { in foreign currency - } \\
6-8 \%\end{array}$ & $\begin{array}{l}1 \% \text { of the loan } \\
\text { amount }\end{array}$ & $\begin{array}{l}\text { capital financing, investment loans, } \\
\text { credit lines, overdrafts, deposit loans. }\end{array}$ \\
\hline Credit Dnipro & $\begin{array}{l}\text { from } 300,000 \mathrm{UAH} \\
\text { to } 5,000,000 \mathrm{UAH}\end{array}$ & in hryvnia - 14-21\% & $\begin{array}{l}1 \% \text { of the loan } \\
\text { amount }\end{array}$ & $\begin{array}{l}\text { Capital financing, investment loans, } \\
\text { promissory note programs, bank guarantees, } \\
\text { credit lines }\end{array}$ \\
\hline Credit Agricole & $\begin{array}{l}\text { the minimum is } \\
1,000,000 \mathrm{UAH}, \\
\text { the maximum is } \\
\text { determined by the } \\
\text { borrower's financial } \\
\text { condition }\end{array}$ & $\begin{array}{l}\text { in hryvnia - } 16-17 \% \text {, } \\
\text { in foreign currency - } \\
\quad 4.5-5.5 \%\end{array}$ & $\begin{array}{l}1 \% \text { of the loan } \\
\text { amount }\end{array}$ & $\begin{array}{l}\text { working capital financing, investment loans, } \\
\text { credit line, overdraft, project financing, } \\
\text { deposit loans, export / import financing, } \\
\text { factoring, promissory note avalization, bank } \\
\text { guarantees, agricultural insurance }\end{array}$ \\
\hline UkrSibbank & $\begin{array}{l}\text { more than } \\
20,000,000 \text { USD }\end{array}$ & $\begin{array}{c}\text { in } \mathrm{UAH}-14.9 \% \\
\text { for small and medium } \\
\text { business }\end{array}$ & $\begin{array}{l}\text { depends on the } \\
\text { specific case }\end{array}$ & $\begin{array}{l}\text { working capital financing, credit lines, } \\
\text { export / import financing, bank guarantees } \\
\text { and partnership proposals for financing } \\
\text { farmers under forward contracts with buyers }\end{array}$ \\
\hline Ukrgasbank & $\begin{array}{l}\text { for small and medium } \\
\text { business - more than } \\
\text { 10,000,000 UAH. }\end{array}$ & $\begin{array}{c}\text { in hryvnia - 19-21\%, } \\
\text { for SMEs in hryvnia - } \\
\quad 14.6-19.5 \%\end{array}$ & $\begin{array}{l}0.5-1 \% \text { of the loan } \\
\text { amount }\end{array}$ & $\begin{array}{l}\text { working capital financing, investment loans, } \\
\text { credit line, overdraft, project financing, } \\
\text { deposit loans, export / import financing, } \\
\text { bank guarantees. }\end{array}$ \\
\hline
\end{tabular}

Source: (Mulyk T. and Mulyk Y., 2020)

development of microcredit in Ukraine can be divided into two groups: problems facing small and mediumsized businesses, and problems for banking institutions.

Problems, that prevent banking institutions from more actively developing microcredit for small and medium enterprises include the high cost of resources in the country's banking system and their short-term nature; small amounts of financial support from international financial institutions and business support funds; significant risks to the functioning of the small and medium business segment; low level of quality of credit applications of clients; insufficient development of microcredit technology in banks; insufficient protection of creditors' rights at the level of legislation and the judiciary; underdevelopment of credit bureaus (Sorokivska, 2014).

Despite the fact that microcredit in Ukraine has some restraining factors, it is developing, but at the same time, there are some points, that need to be improved.

O. Radchenko and L. Luzina believe that a necessary condition for further development of microcredit of small agricultural enterprises is to streamline this process, bring it to certain rules, in a qualitatively new regulatory field for standardization of procedures, that is involvement and dominance of the state in this process. They note, that it is also necessary to intensify the activities of credit and guarantee institutions, increase the share of public spending on small business 
development, develop financial support programs on the example of foreign countries, especially Poland, whose experience in microcredit shows that this mechanism is much more effective than the programs of commercial banks, the EU member states, the USA (Radchenko and Lazutina, 2018).

Svinchuk A.A. proposed a number of measures to improve the domestic microcredit system, which can be grouped into the following areas: creation and improvement of the regulatory framework for microfinance/microcredit, credit unions; improvement of existing state mechanisms for the development and support of microcredit; development of a guarantee system for both creditors and union members; ensuring the protection of credit unions; construction of a multilevel system of credit cooperation; promoting the development and transformation of credit unions into public banks; provision of educational and information services for microcredit borrowers; monitoring and control over the activities of credit unions (Svynchuk, 2015).

An effective way to support small business in the agricultural sector is to promote the attraction of foreign investors, which can be achieved through the following measures: removal of legal and administrative barriers to foreign investment; providing tax benefits to enterprises that direct funds to the development of their own production, accompanied by the creation of new jobs; providing tax benefits for companies operating in priority areas. The experience of the Czech Republic is useful for Ukraine in terms of attracting foreign investment, where foreign investors are offered low interest rates on loans for further development and expansion, attractive interest rates on deposits, provide preferential lending conditions for the purchase of real estate (Mulyk T. and Mulyk Y., 2020).

For Ukraine, one of the promising areas for improving the credit infrastructure is the creation of a specialized bank for lending to agricultural enterprises, as well as the development of a three-tier system of credit cooperation on the model of developed countries, including Germany and France. These measures should partially solve the problem of financial support for the activity of agricultural enterprises (Grubinka, 2016).

In general, all measures of state support for lending to agricultural enterprises can be formed into 3 groups:

- measures of direct allocation of funds or compensation to the enterprise, carried out individually at the enterprise by direct allocation or transfer of funds, when a certain part of the loan rate is reimbursed;

- measures to compensate and support credit institutions, that provide loans to agricultural enterprises by changing the reservation norms, or their preferential lending, which depends on the volume of loans to agricultural enterprises in the structure of the loan portfolio of the institution;
- measures to create specialized credit institutions for lending to the agricultural sector, based on the need for low profitability, control over public funds and strategic importance and individual approach to this industry (Grubinka, 2016).

Interest rates on loans, raised to cover the costs, associated with the purchase of fuels and lubricants, seeds, fertilizers, plant protection products, feed, raw materials and ingredients for the production of feed, veterinary drugs, young farm animals and poultry, equipment for livestock farms and complexes, spare parts for repair of agricultural and irrigation machinery and equipment, energy, and payment for services related to repair works, works (services) for soil preparation and cultivation, protection of plants from diseases and pests, are subject to compensation (Radchenko, 2020).

Each of these groups has its advantages and disadvantages, depends on the characteristics of the country's economy, the state of its credit system, agricultural and economic policy. It is possible to combine these groups of support measures, as they are not mutually exclusive and depend on the country's financial capabilities and the development of its credit infrastructure. Characteristically, successes in lending to agricultural enterprises are observed in countries that use measures from different groups, respectively, we can talk about the dependence of the effectiveness of a measure from the thoughtfulness and its careful implementation, as well as securing financial resources for it and transparency and clarity of access to it and its use. Thus, high results in lending to farms have been achieved in countries with specialized credit infrastructure (Germany, France, Indonesia, Tunisia), in the US we see a high efficiency of combining specialized credit institutions and direct support measures against the background of a high degree of development of the land and stock market, which is especially noticeable when lending to farmers (Grubinka, 2016).

Analyzing the foreign experience of microcredit to small and medium-sized businesses, O.I. Masna in her study notes, what should be done in Ukraine: to create separate non-profit microfinance institutions which would be endowed with the rights of crediting of the enterprises of small and average business; to create appropriate structural subdivisions or small sectors in banking institutions, which would be engaged only in studying the demand for microcredit and would study the history of small enterprises activity; to finance more actively small and medium-sized businesses that use energy-saving technologies and produce energyintensive products; to introduce a system of guaranteeing micro credits by local authorities or various funds; to promote more efficient lending to small businesses that export products or produce products that reduce imports; develop national and regional programs for micro-lending to small and medium-sized businesses by the non-banking system (credit unions, insurance and 
leasing companies, etc.); to expand the system of training and retraining of entrepreneurs, especially in matters of microcredit to small businesses (Masna, 2008).

\section{Conclusions}

The support of small businesses in the agricultural sector through lending mechanisms is important and is currently carried out in different areas and conditions, both by commercial banks and by various funds and organizations. Microcredit is an important and one of the most promising tools in promoting the development of small and medium enterprises. However, the high level of risk of such operations significantly reduces the activity of banks in this direction. Therefore, to ensure full credit financing of small and medium-sized businesses, it is necessary to establish a mechanism for its support by the state.

Microcredit is one of the elements of financing, which involves the provision of a small amount by a bank or other organization. The main idea of microfinance correlates with the idea of social entrepreneurship and is to overcome poverty, ensure the economic sustainability of socially unprotected groups of population and support their integration into the labor market through the development of small businesses.

It has been established, that the volumes of attracted short-term loans in the agricultural sector account for a significant amount of small and micro enterprises, but it should be remembered, that there are more of them. Thus, in 2019 the volume of loans to small enterprises amounted to 23,293.3 million UAH, which means that they increased compared to 2013 by $17,978.1$ million UAH. The share of loans to these entities increased by $20.63 \%$. Among the loans to small enterprises in the agricultural sector, a significant share falls on loans to micro-enterprises, their share ranges from $30-58 \%$.
According to the results of the study, the rating of domestic banks that offer the most favorable lending conditions for agricultural enterprises is given. It is established that OTP Bank is in the lead. In its activities, loans issued to the agricultural sector account for up to $50 \%$ of OTP Bank's total loan portfolio. The bank finances not only agricultural producers, but also traders, suppliers of seeds, fertilizers, plant protection products, machinery and fuel.

The problems that prevent banking institutions from more actively developing microcredit for small and medium enterprises are the high cost of resources in the country's banking system and their short-term nature, small amounts of financial support from international financial institutions and business support funds, significant risks to the functioning of the small and medium business segment; low level of quality of credit applications of clients; insufficient development of microcredit technology in banks; insufficient protection of creditors' rights at the level of legislation and the judiciary; small amounts of financial support from international financial institutions and business support funds; underdevelopment of credit bureaus.

The main directions of further development of microcredit in the agricultural sector of Ukraine's economy should be: the creation and improvement of the regulatory framework for microfinance/ microcredit, credit unions; improvement of existing state mechanisms for the development and support of microcredit; development of a guarantee system for both creditors and union members; ensuring the protection of credit unions; construction of a multilevel system of credit cooperation; promoting the development and transformation of credit unions into public banks; providing training and information services for microcredit borrowers; monitoring and control over the activities of credit unions.

\section{References:}

Grubinka, I. V. (2016). Directions for improving the credit security of agricultural enterprises in Ukraine through the prism of foreign experience in its implementation. Collection of scientific works, vol. 2, pp. 112-122.

Activities of large, medium, small and micro enterprises: a statistical collection. (2020) Kyiv. Available at: http://www.ukrstat.gov.ua/druk/publicat/kat_u/2020/zb/12/Dsvsmm_19.pdf

Kiyoshi, Abe (2005). Microcredit: Eastern Europe and Ukraine. Journal of European Economy, no. 3, pp. $307-327$.

Masna, O. I. (2008). Financial support of microcredit of small and medium business in Ukraine: author's ref. dis ... cand. econ. science: 08.00.08. NAS of Ukraine. Inst region. research. L., 20 p.

Mulyk, T. O., Materinska, O. A., \& Plonsak, O. L. (2017). Analysis of economic activity: a textbook. Kyiv: Center for Educational Literature. (in Ukrainian)

Mulyk, T. O., \& Mulyk, Y. I. (2020). Microcredit of the agricultural sector in Ukraine: status, problems and prospects. Gesellschaftsrechtliche Transformationen von wirtschaftlichen Systemeninden Zeiten der Neo-Industrialisierung. Kornieiev V., Pasichnyk, Yu., Radchenko O., Khodzhaian A. undandere: Collective monograph. Verlag SWG imex $\mathrm{GmbH}$, Nuremberg, Germany, pp. 432-445.

Mulyk, T. O. (2020). Environmental impact assessment of agriculture: regional aspect. Modern Economics, no. 19, pp. 135-142.

Reliable leverage: TOP-15 banks lending to the agricultural sector (2018). Available at: https://landlord.ua/ reytingi/nadiyne-pleche-top-15-bankiv-shho-kredituyut-agrosektor (accessed 10 January 2021).

On the State Budget of Ukraine for 2020: Law of Ukraine of November 14, 2019. № 294-IX. 
Pravdyuk, N. L., Mulyk, T. O., \& Mulyk, Y. I. (2019). Management of financial security of enterprises: accounting and analytical aspect: monograph. Kyiv: Center for Educational Literature. (in Ukrainian)

Radchenko, O., \& Lazutina, L. (2018). Support of rural entrepreneurship through microcredit mechanisms. Agricultural science and education in the context of European integration: a collection of scientific papers intern. scientific and practical conf. Part 2. (March 20-22, Kamyanets-Podilsky). Ternopil: Krok, pp. 203-206.

Radchenko, O. D. (2020). Formation of agrarian microcredit system. Entrepreneurship in the agricultural sector: global challenges and effective management: materials of the I International scientific-practical conference (February 12-13). Zaporizhzhia: ZNU, pp. 232-235.

Svynchuk, A. A. (2015). Microcrediting of social enterprises in Ukraine: state and prospects of development. Financial Space, no 2, pp. 343-348.

Sorokivska, Z. (2014). Characteristics and problems of microcredit development in Ukraine. Ukrainian Science: past, present, future: yearbook: in 2 parts ed. M. V. Lazarovich; ed.board.: S. V. Adamovich, V. Ya. Brych, O. E. Homotyuk [etc.]. Ternopil: TNEU, Vol. 19; part 1, pp. 138-145. 